\title{
The change in pulmonary vascular resistance after left ventricular assist device implantation - the pre- dictive role of platelets revisited
}

\author{
Marijan Pašalićc ${ }^{*}$, Maja Čikeš ${ }^{1}$, Boško Skorić ${ }^{1}$, Hrvoje Gašparović', Tomislav Ćaleta ${ }^{2}$ \\ Jelena Forgač², Tea Grgićc ${ }^{2}$ Željko Baričevićc, Lucija Svetina1, Mate Petričević', Višnja Ivančan', \\ Bojan Biočina', Davor Miličić' \\ ${ }^{1}$ University of Zagreb School of Medicine, University Hospital Centre Zagreb, Zagreb, Croatia \\ ${ }^{2}$ University of Zagreb School of Medicine, Zagreb, Croatia
}

Purpose: While analyzing the group of patients implanted with a left ventricular assist device (LVAD) at our institution to verify which of the pre- and postoperative factors constitute the optimal survival outcome predictors, we determined a significant increase in postoperative pulmonary vascular resistance (PVR) values in the expired patients1. The aim of this study was to further analyze the data in order to determine which of the preoperative factors were related to the aforementioned increase in postoperative PVR values.

Methods: For the 20 patients ( $18 \mathrm{M}, 2 \mathrm{~F}$; mean age $58.7 \pm 8.3$ years) that have been implanted with an LVAD in our institution during the past 2 years, preimplantation echocardiography, right heart catheterization $(\mathrm{RHC})$ and laboratory data were collected and compared according to the values of the postimplantation PVR. The groups were compared by using the adequate statistical test (t-test, Mann Whitney $U$ test, statistical significance set at 0.05). Correlation analysis and linear regression were performed.

Results: Among the 20 patients, 14 had postoperative $\mathrm{RHC}$ data and 4 of them were proven to have elevated PVR values (>2.4 WU). When comparing the pts. with elevated to

\section{Received: $1^{\text {st }}$ May 2014}

*Address for correspondence: Klinički bolnički centar Zagreb, Kišpatićeva 12, HR10000 Zagreb, Croatia.

Phone: +385-1-2367-467

E-mail: marijan.pasalic@yahoo.com those with normal PVR values, no significant difference was found neither in the RV function (FAC $33 \pm 7 \%$ vs $22 \pm 12 \%$, TAPSE $1,0 \pm 0,7 \mathrm{~cm}$ vs $1.6 \pm 0.5 \mathrm{~cm}, \mathrm{NS})$, nor in the RV and LV dimensions (RVIDd $34 \pm 9 \mathrm{~mm}$ vs $35 \pm 12 \mathrm{~mm}$, LVIDd $65 \pm 10 \mathrm{~mm}$ vs $73 \pm 9 \mathrm{~mm}$ ). The borderline significance was found in the left ventricular EF ( $28 \pm 3 \%$ vs $19 \pm 8 \%, p=0.06)$ and the degree of the MR (median values 1 vs $2, p=0.05$ ). The preoperative $\mathrm{RHC}$ parameters were not found to be predictive of changes in postoperative PVR (preoperative PVR $4,2 \pm 3,4$ vs $3,4 \pm 1,5$ WU, C.I. $1,8 \pm 0,7$ vs $1,9 \pm 0,4$ $\mathrm{L} / \mathrm{min} / \mathrm{m}^{2}$, TPG $14 \pm 11$ vs $13 \pm 4 \mathrm{mmHg}$ and RVSWI $11,4 \pm 2,2$ vs $8,9 \pm 2,1, N S)$. As for the laboratory values, only the platelet count significantly differed between the groups (128 \pm 73 vs $\left.246 \pm 65 \mathrm{E} 3 / \mathrm{mm}^{3}, \mathrm{p}<0.05\right)$. The correlation analysis showed a strong negative correlation between the platelet count and postoperative PVR values $(r=-0,761, p<0.01)$. The linear regression verified the following relationship between the variables PVR=6,247-0,017xPLT, $p<0.01$ ).

Conclusion: These preliminary data show that the platelet count is a significant predictor of the postoperative PVR values in patients with an LVAD (a previously shown survival predictor1). Further investigation will be conducted to explain the role of platelets in the etiology of PVR in our group of pts.

KEYWORDS: left ventricular assist device, pulmonary, vascular, resistance, platelets.

CITATION: Cardiol Croat. 2014;9(5-6):232.

\section{Literature}

1. Cikes M, Skoric B, Pasalic M, et al. The change in pulmonary vascular resistance after LVAD implantation - can it aid in predicting postimplantation survival? $\mathrm{J}$ Heart Lung Transplant. 2014;33(4 Suppl):S263. 